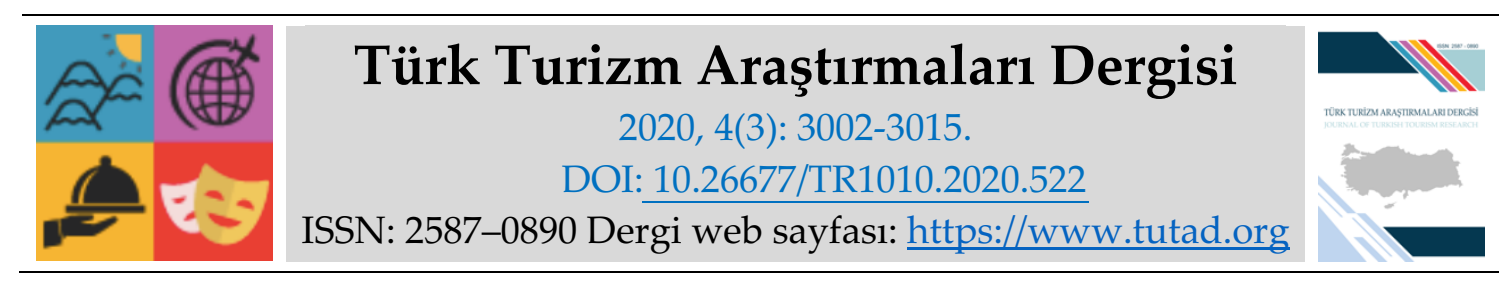

$\underline{\text { KAVRAMSAL MAKALE }}$

\title{
Damla Sakızının Türk Mutfağındaki Yeri, Önemi ve Kullanım Alanları
}

Öğr. Gör. Cansu AĞAN, İstinye Üniversitesi, Güzel Sanatlar, Tasarım ve Mimarlık Fakültesi, İstanbul, e posta: cagan@istinye.edu.tr ORCID: https://orcid.org/0000-0001-9043-8767

Dr. Öğr. Üyesi Çağla ÖZER, İstinye Üniversitesi, Güzel Sanatlar, Tasarım ve Mimarlık Fakültesi, İstanbul, e posta: cozer@istinye.edu.tr ORCID: https://orcid.org/0000-0001-8471-8607

Öz

Geçmişten günümüze kadar köklü bir kültürel değere sahip olan Türk mutfağı, kullanılan malzemelerin çeşitliliği açısından zengin bir mutfak olup geleneksel ve yöresel yemekleri ile dikkat çekmektedir. Damla sakızı, Akdeniz ve Ege adalarında 2-3 metre boyunda olup kendiliğinden yetişen Anacardiaceae familyasına ait olan sakız ă̆acının (Pistacia lentiscus L.) gövde ve dallarının çizilmesi ile elde edilen doğal reçinedir. Saydam ve hoş kokulu bir ürün olan damla sakızı Türk mutfağında yemeklerde, içeceklerde ve özellikle sütlü tatlılarda koku, tat ve aroma özelliklerinden dolayı sıklıkla kullanılmaktadır. Bu çalışmada damla sakızının genel özellikleri, tarihçesi, insan sağlığına etkisi ve Türk mutfağında kullanım alanları hakkında 1984-2020 yılları arasında yayınlanan çalışmalar (araştırma makaleleri, derlemeler, lisansüstü tezler, kongre bildirileri, kitaplar) taranmış ve elde edilen veriler başlıklar halinde bir derleme çalışması haline getirilmiştir. Damla sakızının üretim arttırma çalışmalarının yapıldığı, konu ile ilgili etkinlik ve festivallerin var olduğu görülmüştür. Ayrıca Osmanlı döneminden günümüze aktarılan ve damla sakızı ihtiva eden bazı reçetelerin günümüzde geleneksel olarak kullanılıyor olduğu belirlenmiştir.

Anahtar Kelimeler: Damla sakızı, Gastronomi, Türk Mutfağı, Yiyecek kültürü, Yöresel Yemek.

Makale Gönderme Tarihi: 04.03.2020

Makale Kabul Tarihi: 07.07.2020

\section{Önerilen Atıf:}

Ağan, C. ve Özer, Ç. (2020). Damla Sakızının Türk Mutfağındaki Yeri, Önemi ve Kullanım Alanları, Türk Turizm Araştırmaları Dergisi, 4(3): 3002-3015.

(c) 2020 Türk Turizm Araştırmaları Dergisi. 


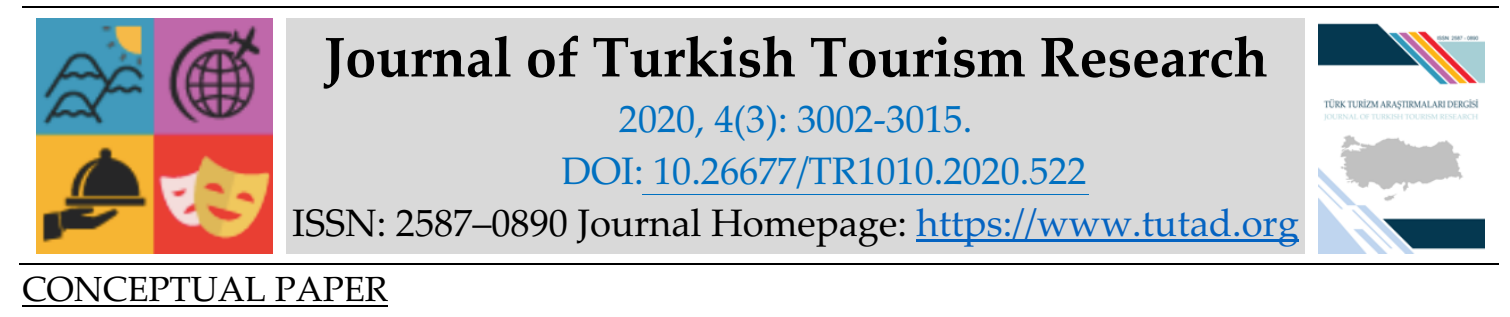

\title{
The Role, Importance and Areas of Usage Mastic Gum in Turkish Cuisine
}

Lecturer Cansu AĞAN, İstinye University, Faculty of Fine Arts, Design and Architecture İstanbul, e mail: cagan@istinye.edu.tr ORCID: https://orcid.org/0000-0001-9043-8767

Assistant Prof. Dr. Çağla ÖZER, İstinye University, Faculty of Fine Arts, Design and Architecture, İstanbul, e mail: cozer@istinye.edu.tr ORCID: https://orcid.org/0000-0001-8471-8607

\begin{abstract}
Turkish cuisine, which has a rooted cultural value from the past to the present, has rich in the variety of materials used and attracts attention with its traditional and regional dishes. Gum mastic is a natural resin obtained by drawing the stems and branches of the Mastic tree (Pistacia lentiscus L.), which belongs to the Anacardiaceae family, which is 2-3 meters tall in the Mediterranean and Aegean islands. Mastic gum which is a clear and aromatic product, is also included in dishes and drinks in Turkish cuisine as a spice and main ingredient due to its fragrance, taste and aroma characteristics. In this study, the studies (research articles, reviews, postgraduate thesis, congress proceedings, books) which published between 1984-2020 on the general characteristics, history, effect of human health and usage areas in Turkish cuisine of gum mastic were scanned and the data obtained were compiled into titles. It is observed that production enhancement studies of gum mastic are carried out and there are activities and festivals related to the subject. Additionally, it has been determined that some recipes which contain gum mastic and have been transferred from the Ottoman period to the present, are traditionally used today.
\end{abstract}

Keywords: Food Culture, Gastronomy, Gum Mastic, Local Cuisine, Turkish Cuisine Received: 04.03.2020

Accepted: 07.07.2020

\section{Suggested Citation:}

Ağan, C. and Özer, Ç. (2020). The Role, Importance and Areas of Usage Mastic Gum in Turkish Cuisine, Journal of Turkish Tourism Research, 4(3): 3002-3015.

(C) 2020 Türk Turizm Araştırmaları Dergisi. 


\section{Gíriş}

Damla sakızı, Anacardiaceae familyasına ait olan sakız ağacından (Pistacia lentiscus L.) elde edilen ve hemen hemen bütün Akdeniz'e kıyısı olan ülkelerde ve özellikle Ege Denizi adalarında doğal olarak yetişen ağacın reçinesi olup anavatanı, adını da bu bitkiden alan Sakız Adası' dır (Çalışkan, 2018). Yunanca "Mastika" ve Osmanlı kayıtlarında da "Mastaki" olarak geçen damla sakızının diğer bir adı da "Gözyaşı"dır. Damla sakızının gözyaşı olarak anılmasındaki rivayete göre; 3.yüzyılda yaşamış olan ve sakız ağaçlarının konumlandığı bölgede katledilen Hristiyan azizlerinden Agios Isidoros'un ölümüne şahit olan sakız ağaçlarının ağlamaya başladığı, gözyaşı olarak nitelendirilen ise ağacın reçinesi olduğu ve ağaçların hâlâ ağladığı söylenmektedir (Yaşar Keskin, 2013). Ayrıca damla sakızı, "sakız reçinesi", "gum mastic (doğal sakız reçinesi)" veya "Chios mastic" olarak da adlandırılmaktadır (Erdönmez, 2018).

Günümüzde sadece ticari olarak Yunanistan'ın Sakız Adası'nda üretilmekte olup ham şekliyle veya işlenerek farklı sektörlerde ve farklı ürünlerde kullanılmaktadır (Çalar, 2013). Diğer Akdeniz'e kıyısı olan ülkelerde de yetiştirilebilen sakız ağacından, Sakız Adası'ndakinden alınan verimlilik ve ürün kalitesinin düşük olmasında adanın çevresindeki su altı volkanların etkili olduğu düşünülmektedir (Yaşar Keskin, 2013). Damla sakızı, gıda korumada, hazmı kolaylaştırmada, birçok sağlık ürünlerinin yanı sıra Türk mutfağında lokum, dondurma, sütlaç gibi sütlü tatlılar ile birçok yemekte temel aroma maddesi olarak kullanılmaktadır (Akdemir vd., 2013; Erdönmez, 2018; Kılıç, 2019). Bunun yanı sıra yalnızca damla sakızı değil sakız ağacının da Türk mutfağında kullanımı bulunmaktadır. Muğla'da yapılan Sakızdırık köftesinde sakız ağacından yapılan çöp şişlerin kullanılması dolayısıyla bu ismi aldığı söylenmektedir (Çelik vd., 2020).

Bu çalışmada damla sakızının genel özellikleri, tarihçesi, insan sağlığına etkisi ve Türk mutfağında kullanım alanları hakkında 1984-2020 yılları arasında yayınlanan çalışmalar (araştırma makaleleri, derlemeler, lisansüstü tezler, kongre bildirileri, kitaplar) taranmış ve elde edilen veriler başlıklar halinde bir derleme çalışması haline getirilmiştir.

\section{Damla Sakızının Tarihi ve Üretimi}

Sakız Adası'nda yapılan arkeolojik araştırmalar sonucunda, 6 bin yıllık sakız ağacının (Pistacia lentiscus L.) yaprak fosillerinin bulunması anavatanının Sakız Adası olduğunu göstermektedir. Sakız ağacı, Akdeniz'e kıyısı olan ülkelerden özellikle Yunanistan, Türkiye, İtalya ve İspanya'nın kıyı bölgelerinde doğal olarak yetişen Pistacia cinsinin 14 türünden birisidir (Onay vd., 2016). 2-3 metreye kadar uzayabilen, kendiliğinden yetişen ve dalları sik olan bir bitkidir. Temmuz ve ağustos aylarında gövde ve dallarına yatay olacak şekilde çentikler açlmakta ve gözyaşı şeklinde "Schinos" olarak bilinen sarımtırak ve saydam damlalar halinde reçine akmaktadır (Emecen, 2011; Çalışkan, 2018). Sıvı olan reçine kuruduktan sonra oda sıcaklığında oldukça sert ve kırılgan bir yapı haline gelmekte ve reçinenin, Roma İmparatorluğu döneminde yaşamış olan Yunanlı hekim ve farmakoloji alanında uzman olarak bilinen Dioscorides Pedenius zamanından beri toplanıp sağlık, kozmetik ve yemek yapımında kullanıldığı bildirilmektedir (Hakgüder Taze vd., 2014). Damla sakızı, narenciye ve hoş odunsu bir kokuda, ekşimsi tatta, canlı ve taze görünümde karakterize edilmekte, bununla birlikte içerisinde uçucu yă̆, masticin, reçine, reçine asidi, alkol de bulunan bir ürün olarak tanımlanmaktadır (Yaşar Keskin, 2013; Rigling vd., 2019). Ayrıca fenolik bileşikler de dâhil olmak üzere çok sayıda biyoaktif bileşen içerdiği, monoterpen ve triterpen gibi terpenlerin kaynağı olduğu bildirilmiştir (Papada ve Kaliora, 2019). Bunların haricinde damla sakızında renk önemli bir kalite kriteri olup, okside olmuş sarı renklilerin tercih 
edilmediği, daha temiz ve şeffaf renkli olanların daha kaliteli olduğu, şeffaf ve cam boncuk gibi görünenlerin ise en kaliteli olduğu belirtilmektedir (Akdemir vd., 2013).

Sakız Adası'nda ilk üretim ve tarımının başlangıcı Orta Çağ olarak gösterilmekte, daha sonrasında adaya sırasıyla Bizans İmparatorluğu ve Cenovalıların hüküm sürdüğü ve 1566 yılında Kanuni Sultan Süleyman döneminde Kaptan-ı Derya Piyale Paşa tarafından Osmanlı İmparatorluğunun egemenliğine geçen adada sakızın oldukça önemsendiği bilinmektedir (Berbercan, 2016). Osmanlı' da damla sakızı padişaha ait has gelir olarak kabul edilip en iyi kalite damla sakızı olan beyaz ve iri taneliler saraya gönderildikten sonra geri kalan damla sakızının ise ticareti yapıldığı bilinmektedir (Emecen, 2011; Yaşar Keskin, 2013).

Ülkemizde sakız ağacı öncelikle İzmir'in Çeşme ve Karaburun ilçeleri başta olmak üzere Muğla ve Antalya' da da doğal olarak yetişmekte ve bu bölgelerde yetiştiriciliğinin yapılabileceği alanlar bulunmakta ve ayrıca Çeşme ilçesinin sakız ağacı potansiyeli, Sakız Adası'ndan daha iyi olduğu ancak ağaçların ya üretim yapılamayan ya da terbiye edilmeyen çalı formundaki ağaçlar olduğu belirtilmektedir (Kılınç, 2013; Onay vd., 2016). Bu amaçla Falım sakızları (Cadbury) ve TEMA Vakfı İzmir Gülbahçe'de, İzmir Yüksek Teknoloji Enstitüsü araştırma sahasında “Bozuk Sakız Ağacı Rehabilitasyonu Projesi" ile sakız ağaçlarının aşılanması yoluyla, damla sakızı üretiminin gerçekleştirilmesi ve ülkemize ekonomik girdi sağlanması hedeflenmiş bu proje sonrasında UrlaKadıvacık 95 Numaralı bölmede "Sakız Ağacı Klon Parkı" projesi 2012-2015 yılları arasında tamamlanarak 108 adedi erkek, 16 adedi dişi olmak üzere toplam 124 klon, 935 bireyi koruma altına alınıp, 2015 yılında tamamen Orman Genel Müdürlüğü'ne teslim edilmiştir (Kılınç, 2013; Kılıç, 2019). Morkan (2009) sakız ağacının İstanbul Burgaz Ada'da, İzmir, Ankara İncesu'da, Kayseri, Muğla Marmaris ve Datça'da ve Aydın Kuşadası'nda, Antalya Kemer'de, Mersin Tarsus'ta, Sivas Ulaş'ta Seyhan ve Hatay kesimlerinde rastlandığını belirtmektedir. Sakız ağaçlarının kesilerek kereste olarak kullanılması, kırsal nüfusun azalması, sakız yetiştiriciliği kültürünün göç eden yerel halk ile birlikte kaybolması ve başka sektörlere verilen öncelikler sebebiyle tarım alanlarının yok edilmesiyle birlikte, ülkemizde sakız ağacı yetiştiriciliği olumsuz olarak etkilenmiş ve 2014-2019 yılları arasında uygulanmak üzere Orman Genel Müdürlüğü tarafından "Sakız Eylem Planı" oluşturulması gerekliliği doğmuştur. Türkiye'nin kültürel, ekonomik ve sosyal bir parçası olan bu ürüne, hak ettiği değeri ve emeği yeniden vermek ve Türkiye'ye tekrardan kazandırılıp, gereksinimi dâhilinde iç kaynaklardan temin etmesi amaçlanmıştır (Orman Genel Müdürlüğü, 2014). Şubat 2020 tarihli Orman Genel Müdürlüğü 2019 yılı İdare Faaliyet Raporu incelendiğinde belirledikleri alanlarda hedefledikleri oranda sakız ormanlarını kurarak hem çevre kirliliği ve ormansızlaşma gibi küresel problemlerin azaltılmasını hem de ekosistem bütünlügünün korunmasına yardımcı olarak önemli başarı sağlamışlardır.

Kılıç (2019), Sakız Adası Damla Sakızı Üreticileri Birliği'nin çatısı altında Türkiye'nin de içinde bulunduğu 22 farklı kooperatif barındırdığı, mastihashop olarak kurulan mağazaları aracılığıyla damla sakızlı ürünleri pazara sunduğunu ve bu ürünler 1997 yılında Avrupa Birliği'nden AET 2081/92 yönetmeliği uyarınca coğrafi işaret aldığını ve 2016 yılında agroturizm faaliyetlerini arttırmak amacıyla Sakız adasının güneyinde sakız ağacı temalı bir müzenin açıldığını bildirmektedir.

\section{Damla Sakızının Sağlık Üzerine Etkileri}

Damla sakızı, tıp ve ilaç sektöründe önemli bir yere sahiptir. İlk çağdan itibaren kayıtlara geçen bilgilere göre, "tıbbın babası" olarak bilinen Hipokrat, sakız ağacından elde edilen reçinenin kadın hastalıkları üzerinde etkili bir ilaç olduğunu belirtmiştir. İbn Sînâ'nın "El-Kânûn Fî́t-Tıbb" adlı eserinde "Geriatri" bölümünde damla sakızının sindirim sistemini düzenleyici olarak kullanılabileceği, mide ve karaciğerin düzenli bir şekilde çalışmasını sağladığını ve beyin 
gelişiminde de etkisi olduğunu söylemiştir (Acıduman ve İlgili, 2010; Tatlı, 2017). Eski Mısır uygarlığında damla sakızı ve reçinesinin soğuk algınlığı rahatsızlıklarında kullanıldığı (Dönmez, 2019), eski Yunanlıların ise damla sakızını, yatıştırıcı ve antibakteriyel özellikleriyle, mide ve karın ağrısı gibi rahatsızlıklar için kullanıldığı söylenmektedir (Marone vd., 2001). Ayrıca damla sakızının diş temizlemek ve ağız sağlı̆̆ının korunması amacıyla da çiğnendiği, pastil olarak ve diş tedavilerinde kullanıldığı ve 15. yüzyılda yaşamış olan ünlü hekim Şerefeddîn Sabuncuoğlu "Mücerreb-nâme" adlı eserinde de aynı etkilerden söz ederken üst ve alt solunum yollarını iyileştirici etkisi olduğundan da bahsetmektedir (Uzel, 1984; Şar ve Süveren, 2006; Sargın vd., 2013; Özdoğan, 2018). Hekim Yakup Paşa'nın, Fatih Sultan Mehmet için yaptığı iki ayrı macunda damla sakızını kullandığı ve bel ağrısı, mide ve bağırsak sindirimini kolaylaştırması gibi yararları olduğunu söylemektedir (Davulcu ve Tugay, 2018). Yapılan çalışmalar derlendiğinde damla sakızının; antienflamatuar, antioksidan ve antimikrobiyal özellikler gibi farklı biyolojik aktiviteler gösterdiği ifade edilmektedir (Koutsoudaki vd., 2005; Mahmoudi vd., 2010; Furkan, 2016; Özçelik, 2018). Bu gibi yararların sonucunda damla sakızı, Avrupa Tıp Ajansı Bitkisel Tıbbi Ürünler Komitesi tarafından geleneksel bitkisel tıbbi ürün sınıfında değerlendirilmiştir (Kılıç ve Uysal, 2019).

\section{Damla Sakızının Türk Mutfağında Kullanımı}

Damla sakızı, Türk Mutfağında uzun zamandan beri özellikle et yemekleri ve tatlılarda aromatik koku ve lezzet vermesinin yanı sıra koruyucu özelliği ve raf ömrünü uzatması amacıyla da tercih edilen bir gıda ürünüdür (Orman Genel Müdürlüğü, 2014; Kılıç, 2019). Türk mutfağının yanı sıra Yunan ve Arap mutfağında damla sakızı tozunun tatlandırıcı ve aroma vermek amacıyla gıda katkı maddesi olarak, şeker içeren jel formumun tatlandırıcı olarak, yağının ise içeceklerde tatlılık vermesi amacıyla kullanıldığı bilinmektedir (Triantafyllou vd., 2011). Şekerleme, unlu mamuller ve içeceklere aroma katmak amacıyla kullanımının dışında soslarda kıvam artıırıcı olarak kullanımı bulunmaktadır (Yaşar Keskin, 2013; Özçelik, 2018). En yaygın kullanıldığı ürünler; fırın ürünlerinden ekmek, bisküvi, kek ve krakerlerde, sütlü tatlılardan muhallebi, sütlaç gibi ürünlerde ve bunun yanı sıra helva, lokum, dondurma olduğu bildirilmektedir (Fıtlamak, 2014; Onay vd., 2016). Puding ve dondurmalarda kullanımında ana malzeme olarak yerini almakta açık beyaz renk almasını da sağlamaktadır (Kılınç, 2013). Türk kahvesi, salep ve soda gibi alkolsüz içecekler, sakız likörü gibi alkollü içeceklerde, pilavlarda da tat ve koku verici madde olarak da kullanıldığı ayrıca, yağ ile karıştırılarak balığa sürüldüğünde koku alma özelliğinin olduğu da belirtilmektedir (Orman Genel Müdürlüğü, 2014; Kılıç, 2019).

Osmanlı mutfağında kullanımı incelendiğinde; 13.yüzyılda yaşamış olan Muhammed b. ElKerim tarafından derlenen Kitâbü't-Tabih adlı eserde damla sakızının baharat olarak kullanıldığı ve damla sakızının büyük, beyaz, şeffaf damlalar şeklinde, dövülmemiş ve temiz olması gerektiği yazmaktadır (Pişkin, 2009). Damla sakızı 15.yüzyıldan 19.yüzyıla kadar baharat olarak kullanılmasının yanı sıra özellikle pilav, şerbet, macun ve tatlılarda kullanılan malzemelerden biri olma özelliğini taşımıştır (Yerasimos, 2014b). Muhammed bin Mahmûd Şirvanî tarafından 15.yüzyılda yazılan Mustafa Argunşah ve Müjgân Çakır tarafından derlenen "15.Yüzyıl Osmanlı Mutfağı" adlı eserde damla sakızının kullanıldığı yemekler farklı bölümler içinde tarifleri ve faydaları ile anlatılmış olup şu şekildedir: Ekşi yemekler kısmında "İbrahimiye, Zibac aşı, Nirbac, Tuffahiye, Hısrimiye, Hulviye (Ferhane aşı), Rummaniye (Nar aşı), Ribasiye, Sumakiye, Limoniye, Memkuriye aşı, Hubeyşiye, Zerdali aşı, Narenciye aşı, Narlı sirke aşı, Maseviusiye"; Süt ve un ile yapılan yemekler kısmında "Maziyre, Lebeniye aşı, Mücezzea, Ukeyke aşı, Masliye aşı"; Çorba, pilav ve un ile yapılan yemekler kısmında "Ispanak aşı, Pirinç pilavı, Müceddere aşı, Maşiye aşı, Mukliye aşı, Itriye aşı, Mühellebiye aşı (Bıhtıla aşı)"; Kalye ve naşife ile benzer yemekler kısmında "Anberiye, Ayva 
kalyesi, Turunç kalyesi, Fahitiye kalyesi, Dövülmüş ekşi köfte, Boranı kalyesi, Altın kalyesi, Nergis kalyesi, Soğan kalyesi"; Ekşi ve tatlı konulmayan kalye, boranı ve kavurma türü yemekler kısmında "Reyhaniye kalyesi, Menbuşe kalyesi, Kabak boranısı, Taze bakla kalyesi, Muhfiye kalyesi, Sade köfte, Gürdiye kalyesi"; İçerisinde tatlı malzemeler konulan kalye ve kavurma yemekleri kısminda "Hurma kalyesi"; Herise ve tandırda pişen yemekler kısmında "Kebise, Bumbar, Paça aşı, Tandırda pişen sikbac aşı"; Mutaccan, bevarid, maklube, senbuse ve bu tür de yapılan yemekler kısmında "Masus, Yumurta kavurması"; Balık yemekleri kısmında "Balık biryan"; Huşknan, kadayıf ve içerisine un katılıp bunlara benzer olan yemekler kısmında "Zerbudil" yemekleridir (Argunşah ve Çakır, 2018).

16.yüzyılda Osmanlı döneminde bulunan bazı vakfiyelerde temel gıdaların yanında yemek ve tatlıları lezzetlendirmek için damla sakızı kullanıldığı söylenmekte olup, buğday çorbasında kullanımı bunun örneklerinden biri olarak verilebilir (Kazancıoğlu, 2017). Bununla birlikte Osmanlı Saray mutfağında ekmek ve unlu mamullere de damla sakızının ilave edildiği, Ramazan ayında padişah sofrası için hazırlanan tatlıların içinde damla sakızının kullanıldığı ifade edilmektedir (Özlü, 2011; Akkoyunlu, 2012). Osmanlı zamanında yalnızca Osmanlı saray mutfağında değil İstanbul'da şeker imalatı yapılan imalathanelerde de çeşitli malzemelerle birlikte damla sakızının da konulduğu söylenmektedir (Haydaroğlu, 2003).

Hüdâyî Tekkesi Vakfı'na ve Sultan II. Mahmud dönemine ait olan 1825 ve 1835 yılları arasında kayıt altına alınan "Mecmuâ-i Fevâid" adlı eserde "Koyun külbastı, Müluki sakız helvası, Patlıcan pilavı" isimli yemeklerin içerisinde damla sakızının bulunduğu yazmaktadır (Gündüzöz, 2016). Mehmet Kâmil tarafından 1844 yılında basılan ve ilk Türk yemek kitabı olarak geçen "Melceü't -Tabbâhin (Aşçıların Sığınağı)" isimli eserde de börekler kısmında Sakız böreğinden, Evliya Çelebi'nin Seyahatnâme'sinde ise damla sakızının yiyecek ve içeceklere tat ile koku veren ve hastalığı iyileştirici olarak kullanılan baharat çeşitlerinden biri olduğu söylenmektedir (Acar Tek ve Sürücüoğlu, 2014; Yerasimos, 2014a). Osmanlı mutfağının yabancı dildeki ilk yayın olma özelliğini taşıyan ve 1864 yılında Türâbi Efendi tarafından yazılan ve "A Manual of Turkish Cookery" adı ile İngilizceye çevrilen eserde damla sakızının kitabın yahni ve pilaki kısmında "Yağsız uskumru pilakisi"; pilavlar kısmında "Patlıcan pilavı, yağsız pilav, tavuk pilavı, baş pilavı, susuz pilav"; soğuk tatlılar kısmında ise "badem kurabiyesi"nden bahsetmektedir (Aktürk, 2005; Yerasimos, 2014a; Ayyıldız ve Sarper, 2019).

Yukarıda kısaca bahsedilen ve Osmanlı mutfağında kullanımı açılanan damla sakızı günümüzde Türkiye'nin Cittaslow Başkenti unvanını alan Seferihisar'da "tatlı tarhana" olarak isimlendirilen ve damla sakızı eklenerek tarhana yapıldığı ve 2009 yılında gerçekleştirilen Terra Madre (Toprak Ana) gününde yöresel yemekleri tanıtmak amacıyla misafirlere ikram edildiği bildirilmektedir (Hocaoğlu, 2010). Eskiden zengin tarhanası olarak da bilinen ama halkın günümüzde sakızlı tarhana (Kızsarlı) olarak isimlendirdiği, içerisinde un, süt, damla sakızı, karanfil ve tuz bulunmakta olan bu ürünün Kooperatif tarafından patenti alınmış ve "Anadolu Lezzetleri" adı altında satılan 71 tane üründen biri olma özelliğindedir. Aynı zamanda her yıl Toprak Ana günü dolayısıyla Seferihisar Hıdırlık Tarımsal Kalkınma Kooperatifi, Belediye, Teos Slow Food Birliği tarafından Seferihisar meydanında pişirilerek dağıtılmakta ve ayrıca sakızlı tarhananın hamurundan pişi yapılarak halka ikram edilmektedir (Coşar, 2017). İzmir'in yemek kültürünün tanıtılmasında kullanılan, İl Kültür ve Turizm Müdürlükleri tarafından hazırlanan broşürlerde de yöresel yiyecekler içinde sakız reçelinin olduğu bilinmektedir (Saatcı, 2019). Çanakkale'nin Gökçeada ilçesinde keçi sütü ve nişasta ile beraber damla sakızı da eklenerek "sakızlı muhallebi" adı ile yapılan bir muhallebi ve "damla sakızlı lor kurabiyesi"nin yöresel olarak yapıldığı görülmektedir (Bayrak, 2014; Çavuşoğlu ve Çavuşoğlu, 2018). Damla sakızının,

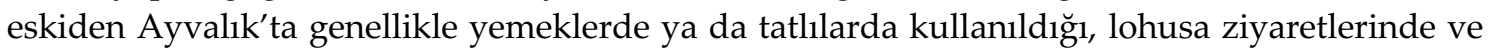
düğünlerde yapıldığı ancak günümüzde bu geleneklerin kalmadığı ve sadece damla sakızlı 
kurabiye olarak yapılıp turistlik ürün olarak pastanelerde satıldığı söylenmektedir (Coşar, 2017; Yılmaz ve Akman, 2018). Damla sakızı reçeli ve şerbetinin Ege Bölgesi'nde hâlâ tüketildiği (Tatlı, 2017) yeni lezzetler elde etmek için Türk kahvesine de damla sakızının eklenebildiği söylenmektedir (Özdamla Akkaya, 2019). Mardin ilinde yaşayan Süryanilerin Türk kahvesini genellikle damla sakızı, kakule gibi ürünlerle aromalandırıp tükettikleri bilinmektedir (Toprak vd., 2018).

\section{Damla Sakızının Kullanıldı̆̆ı Bazı Tarifler}

Türk Mutfağında damla sakızı ile yapılan yemek ve içeceklere ait örnekler tarifleriyle birlikte aşağıda verilmiştir.

\section{Yalancı Tarhana (Taze Tarhana)}

Bilecik ilinde yapılan bir çorba çeşididir. Un, yağ ve salça 2-3 dakika kavrulup, kıvamına uygun olarak sıcak su ilave edildikten sonra karıştırılarak tuz eklenir. Daha sonra havanda dövülmüş damla sakızı ve yoğurt eklenip sürekli karıştırılarak çorbaya eklenir. Piştikten sonra üzerine nane serpilir (Gürsoy, 2016).

\section{Patlicanlı Pilav}

16.yüzyıldan günümüze aktarılan bir pilav çeşididir. Günümüzde bol domatesli pişirilen patlıcanlı pilav 18.yüzyılda ballı, tarçınlı, safranlı ve sakızlı pişerdi. Yerasimos (2014b) tarafından tarifi 1764 tarihli Risaleden alınan reçeteye göre; safran, sirkeli suya konularak 1-2 saat demlendirilir, pirinç yarım saat tuzlu ılık suda bekletilir ve sonra yıkanıp süzülür. Patlıcanın kabukları alacalı olacak şekilde soyulup, ceviz büyüklügünde doğranarak tuzlu kaynar suda 2-3 dakika haşlanıp süzülür. Yemeklik doğranan ve pembeleşinceye kadar kavrulan soğana ilave edilir ve ezmemeye dikkat edilerek kavrulur. Diğer taraftan tencereye 3 bardak sıcak su eklenir, tuz, safran, havanda dövülmüş damla sakızı ve bal eklenir ve bir taşım kaynadıktan sonra pirinç konulur. Tencerenin kapağı kapatılır ve pirinç suyunu çekene kadar 10-15 dakika kısık ateşte pişirilip karabiber ve tarçın ilave edildikten sonra tencerenin ağzı bezle örtülerek demlendirilir.

\section{Rummâniyye (Nar Ekşili Kalye)}

Küçük doğanmış kuşbaşı eti yağda çevrildikten sonra tuz eklenerek sıcak suda pişirilir. Patlıcan ve balkabağı istenilen büyüklükte doğranıp, doğranmış soğanla birlikte tencereye eklenir. Kimyon, kişniş, tarçın, havanda dövülmüş damla sakızı, karabiber ve kuru nane ilave edilerek pişirilmeye bırakılır. Piştikten sonra nar ekşisi, dövülmüş sarımsak ve nane ilave edilip dinlenmeye bırakılır (Güldemir ve Işık, 2012).

\section{Sak1z Yahnisi}

Ege Bölgesi'nde yapılan kuşbaşı et ve arpacık soğandan oluşan ve damla sakızıyla lezzetlendirilen bir yahni çeşididir (Onay vd., 2016). Et yıkandıktan sonra süzülür, suyu çekene kadar kavrulduktan sonra sıcak su ilave edilir. Tencerenin kapağı kapalı olacak şekilde yaklaşık bir saat pişirilir. Arpacık soğan, küp doğranmış domates, sarımsak, sirke, kimyon, tuz ve karabiber eklenip domates suyunu çekene kadar yaklaşık yarım saat pişirilir. Damla sakızı 
havanda tuz ile birlikte dövülüp ilave edilerek ocaktan alınır (Bayrak, 2014). Aynı yemeğin İzmir'de yapılış şekli biraz farklı olup et, arpacık soğan ve damla sakızı dışında domates, portakal kabuğu, defne yaprağı, taze karabiber, kimyon, sarımsak ve çok az da sirke ilave edilmektedir (Gürsoy, 2016).

\section{Bayram Ekmeği}

Balıkesir ilinde yapılan bir ekmek çeşididir. Ekşi maya, un, damla sakızı, tuz, karanfil suyu (3-4 adet karanfil 1 bardak sıcak suyun içerisinde 5 dakika kadar sslatılarak süzülür) ve 1lık su ile ekmeklik hamur hazırlanır. Mayalanması için ekmek hamuru dinlendirilir. Hamurdan yarım ekmeklik parça alınır, uç kısımlara doğru hafif daraltarak elips şekli verilir. Yan yana iki tanesi veya daha küçük hazırlanmış beş tanesi yapışık olarak şekillendirilir. Buna "parmak ekmek" denilir ve iki tanesinin arasına gelecek şekilde burma şerit de konularak süslenir. Özellikle bayramlarda hazırlandığında içine karanfil tozu konulur ve bayramlarda yapıldı̆̆ 1 için "bayram ekmeği", şekli nedeniyle "parmak ekmek" adları verilmiştir (Taşlı ve Kahraman, 2015; Demirel ve Karakuş, 2019).

\section{Gebze Bayram Çöreği}

Kocaeli'nin Gebze ilçesinde Ramazan ve Kurban Bayramı'nda yapılan, anason, tarçın, karanfil, damla sakızı, yağ, şeker, ceviz, susam, çörek otu, çavdar unu, beyaz un, su ve tuz ile yapılan dışarıda 5 gün buzdolabında ise 15 gün taze olarak kalabilen "bayram çöreği” olarak adlandırılan bir çörektir (Üzümcü vd., 2017).

\section{Mahlepli Çörek}

Bursa ilinin Mudanya ilçesinin bir kasabası olan Tirilye'de nişan günü damat ailesinin kız evine cevizli baklava ile ikramlık olarak götürdügü bir hamur işidir. Kızdırılmış zeytinyağı unun üzerine dökülerek hamur haline gelene kadar yoğrulduktan sonra ortası havuz gibi açılır. Az şekerli süt ile ezilmiş maya, yumurta beyazı, tuz, damla sakızı, şeker, mahlep ve anason eklenip yoğrulur. Hamur dinlenmeye bırakılır. Mayalanan hamurdan koç, saç örgüsü, yumurtalı gödek (içinde yumurta olan sepet şeklinde çörek) şekilleri hazırlanır, üzerine sırasıyla yumurta sarısı, tarçın ve susam sürülerek parmaklarla çöreklerin üzerine parmak izi şekli verilir. Diğer bir süslemede çatal yumurtaya batırıldıktan sonra çöreklerin üzerine çeşitli şekiller yapılır. En son olarak daha önceden kabukları ayıklanmış olan iç badem çöreklerin üzerine yerleştirilir ve taş fırında pişirilir (Tunçdöken, 2009).

\section{Sakızlı Kebap}

Bursa ilinde yapılan bir kebap çeşididir. Et kuşbaşı doğranarak rendelenmiş soğanla kavrulur ve biraz sıcak su eklenir. Et yumuşayıp iyice pişinceye kadar kaynatılır. Et pişerken içine gülsuyunun içinde dövülmüş 3 parça damla sakızı konur. Bir tutam un, dövülmüş sarımsak, tarçın, karabiber, karanfil eklenerek biraz daha kaynatılıp ateşten alınır. Başka bir kapta patatesler haşlanıp sütün içinde ezilerek püre haline getirilir, püre tabaklara konup üzerine etler dizilir (Bursa Esnaf ve Sanatkarlar Birliği, 2012). 


\section{Badem Kurabiyesi}

Osmanlı mutfağının yabancı dildeki ilk yayın olma özelliği taşıyan ve 1864 yılında Türâbi Efendi tarafından yazılan "A Manual of Turkish Cookery" adıyla çevrilen kitapta geçen bir tariftir. Badem, şeker ile birlikte havanda dövüldükten sonra yumurta beyazı, damla sakızı ve tarçın eklenerek havanda iyice dövülür. Karışım hamur kıvamına gelince istenilen şekil verilerek yağlı kâğıt serilen tepsiye dizilir ve üzerine tekrardan yağlı kâğıt konulup yağlı kâğıtların kenarları açılmayacak şekilde kıvrılır ve yaklaşık bir saat pişirilir (Aktürk, 2005).

\section{Gerdan Tatlısı (Gerdaniye)}

İzmir'de yapılan bir tatlı çeşidi olup koyun gerdanından yapılmaktadır. Gerdanın yağları ayıklandıktan sonra üzerini 4-5 parmak geçecek kadar su eklenir. Önce orta sonra kısık ateşte uzun süre kaynatılır ve kaynarken üzerindeki köpügü alınır. Etler kemiğinden ayrılacak kadar iyi piştikten sonra soğumaya bırakılır. Haşlanmış gerdan etleri kemikten ayrılır. Ayıklanan etlerin üzerine gerdan suyu ilave edilerek orta ateşte kaynamaya bırakılır. Bir gün önceden suda bekletilen kayısı ve erikler ilave edilip tahta kaşık yardımıyla karıştırılarak yumuşatıldıktan sonra çubuk tarçın, karanfil, kavrulmuş iç badem, kavrulmuş fıstık, şeker eklenerek karıştırılmaya devam edilir. Son olarak şekerle ezilen damla sakızı ilave edilip biraz daha pişirilir (Gürsoy, 2016).

\section{Sütlü Bulgur}

İzmir'in Karaburun ilçesinde yapılan ve börek harcı veya çorba yapımında kullanılan bir malzemedir. Göce ayıklanıp kepeğinden ayrılır, havanda karanfil ve damla sakızı toz haline getirilir. Süt ocağa konularak kaynatılıp sonrasında göce, irmik ve tuz ilave edilerek pişirilir. Göce yumuşayana kadar devamlı karıştırılır ve üzerine karanfil ve damla sakızı ilave edilip ocaktan alınır ve elde edilen ılık hamur yoğurulup bezlere serilerek güneşte kurutulduktan sonra ufalanır. Sonrasında kevgirden geçirilerek 1-2 gün daha güneşte kurutulup temiz bir bez torba içerisinde muhafaza edilir (Bayrak, 2014).

\section{Sakız (Mastika) Şerbeti}

Havanda dövülerek toz haline getirilen damla sakızı kaynayan suya konulup üzerine şeker ve limon eklenerek karıştırılır ve soğuduktan sonra servis edilir. Hazır olan sakız reçelinin ılık suda eritilip biraz limon suyu eklenerek yapılması da bir diğer yapılışs şeklidir (Tatlı, 2017).

\section{TARTIŞMA, SONUÇ veÖNERILLER}

Bu çalışmada damla sakızının tarihi, genel özellikleri, insan sağlığına etkileri ve Türk Mutfağında kullanım yeri ile ilgili literatür bilgilerinin derlenmesi amaçlanmıştır. Damla sakızı, dünyada sadece Sakız Adası'nda ticareti yapılan ve önemli bir geçim kaynağını oluşturan doğal bir gıda ürünüdür. Antimikrobiyal ve antioksidan gibi biyolojik aktivite gösteren ve fenolik bileşikler içeren sağlığa olumlu etkileri olan bir gıda ürünü olup bu amaçla farklı sektörlerde kullanım alanı bulan Sakız Adası'nın en önemli tarım ürünü olarak kabul edilmektedir. Damla sakızının çeşitli yararlı etkilerinden dolayı geçmişte olduğu gibi günümüzde de sağlık sektöründe kullanılmaktadır. Çalışmamızın konusunu oluşturan Türk mutfağında kullanım alanları incelendiğinde kıvam arttırıcı, aroma verici ve koruyucu özelliklerinden dolayı bazı hamur işi 
çeşitleri, sütlü tatlılar, helva, lokum, dondurma, Türk kahvesi ve yaşamın geçiş dönemlerinden biri olan evlilik törenlerinde yapılan ikramlıklarda var olduğu görülmektedir. Hatta aynı coğrafyada yaşayan farklı etnik kökenli toplumların da benzer ürünleri tüketmesini toplumlararası mutfak etkileşimin yaşandığının bir göstergesi olarak kabul etmek mümkündür. Osmanlı döneminde kullanımında ise kalyeler, boraniler, ekşili yemekler, çorbalar, pilavlar ve tatlılar kategorisinde birçok yemeğin bazen tamamlayıcısı, bazen de baharatı olarak kullanıldığı görülmektedir. Ülkemizde özellikle Çeşme Yarımadası'nda yapılan sakız yetiştiriciliğinin nitelik ve nicelik olarak arttırılmasına ilişkin Tarım İlçe Müdürlükleri tarafından devam eden çalışmalar var olup, sakız yetiştiriciliği için elverişli olan bu tarım alanlarının envanterinin çıkarılması, yok olmakta olan üretimin yeniden canlandırılması, girişimcilere fidan temini konusunda destek olunması gibi konularda öngörülen faaliyetler kapsamında Orman Genel Müdürlügü tarafından 2014-2019 yılları için Sakız Eylem Planı hazırlanmıştır. Bu şekilde, sağlık, kimya ve gıda sektörlerinde çeşitli şekillerde kullanılan damla sakızının, ithal edilmesinin azaltılması hatta ülke gereksinimin iç kaynaklardan sağlanacağı düşünülmektedir. Bununla birlikte ülkemizin sahip olduğu tarımsal zenginlik coğrafi işaret potansiyelini akıllara getirmektedir. Damla sakızı ile yapılan yöresel ve geleneksel yemeklerimiz ile içeceklerimizin coğrafi işaretli ürünler olarak başvurunun yapılıp tescillenmesi önemlilik arz etmektedir. Böylelikle bölgeye olan talep ve ilginin artması ve destinasyon pazarlamasında bir unsur olarak kullanılması sağlanırken geleneksel ve yöresel ürünlerimiz korunmaya devam edecektir. Yöresel yemeklerimizden biri olan Gebze çöreğinin Gebze Ticaret Odası tarafından Ankara'da 19-21 Eylül 2019 tarihlerinde düzenlenen II. Uluslararası Coğrafi İşaretli Ürünler Zirvesi'nde tanıtımı yapılmış olup, coğrafi işaret alınması için çalışmaların başlatıldığı bildirilmektedir (www.gazategebze.com.tr). Aynı şekilde damla sakızının kullanıldığı diğer yemeklerimizin de bu anlamda başvuru çalışmalarının başlatılması gerektiği düşünülmektedir. Bunun yanı sıra toplumu temsil etme yeteneği, bir kültüre ait olması, ait olduğu gelenek ve değerlerin kaybolma riski taşıması anlamında UNESCO Somut Olmayan Kültürel Miras (SOKÜM) temsili listesinde yer alması için de çalışmaların başlatılması kültürel mirasımızın bir parçasını oluşturan yemek geleneklerimizin korunması bağlamında önem arz etmektedir. Özellikle şerbet içme kültürümüzün çok eskilere dayanması ve günümüzde eskiye nazaran daha az olması nedeniyle "şerbet içme geleneği ve sakız şerbeti" adı ile SOKÜM listesine alınması için envanter çalışmaları yapılması önerilmektedir. Bunun yanı sıra Sakız Adası Damla Sakızı Üreticileri Birliği'nin çatısı altında Türkiye'nin de içinde bulunduğu 22 farklı kooperatif ve ilgili çalışmaları ve bazı ilçelerimizde Terra Madre kapsamında ya da yöresel yemek etkinlikleri sayesinde eski gelenekler ve tatlar yaşatılarak genç kuşaklara aktarılmasına katkı sağlama çabaları az da olsa bulunmaktadır. Bu etkinlikler ve festivallerde damla sakızının yöresel olarak kullanıldığı yiyecek ve içeceklerin var olması ile birçok kişi geleneksel olan bu malzemeyi öğrenme ve tatma olanağına sahip olabilecektir. Bu nedenle hem mutfak kültürümüzde devamlılığını sağlamak hem de gelecek nesillerin faydalanabilmesi için bu tarz etkinlik, festival ve projelerin il ve ilçelerimizde sayıları arttırılabilir. Damla sakızının sağlık üzerine etkileri açısından tüm bilimsel bulguları göz önüne alındığında hem tarihi hem de özellikle gastronomi alanındaki folklorik kullanımları bu ürünün en kuvvetli referansı olup yöresel uygulamalarla geleneklerimizin gelecek kuşaklara aktarılması gerekliliği önem arz etmektedir. Yapılan bu derleme çalışmasında yararlanılan kaynaklar Türkçe, İngilizce ve Osmanlı Türkçesinden günümüz Türkçesine çevrilen kitaplar olup Osmanlı Türkçesi ile yazılan kaynakların kullanılamaması çalışmanın kısıtını oluşturmaktadır. İlerleyen çalışmalarda Osmanlı Türkçesi ile yazılan ilgili kaynak kitapların da incelenmesi konuya daha derin bir anlam kazandıracaktır. 


\section{KAYNAKÇA}

Acar Tek, N. ve Sürücüoğlu, M. S. (2014). Basılmış Olan İlk Türk Yemek Kitabı “Melceü'tTabbahin", Gazi Türkiyat Türkoloji Araştırmaları Dergisi, 1(14): 225-229.

Acıduman, A. ve İlgili, Ö. (2010). İbn Sînâ'nın El-Kânûn Fî́t-Tıbb Adlı Eserinde “Geriatri” ile İlgili Bölümler, Ankara Üniversitesi Tıp Fakültesi Mecmuası, 63(02): 41-47.

Akdemir, Ö. F., Tilkat, E., Onay, A., Kılınç, F.M., Süzerer, V. ve Çiftçi, Y.Ö. (2013). Geçmişten Günümüze Sakız Ağacı Pistacia lentiscus L., Batman University Journal of Life Sciences, 3(2): 1-28.

Akkoyunlu, Z. (2012). Türk Mutfağından Kaybolan Kerkük Yemekleri, Motif Akademi Halkbilimi Dergisi, 5(9): 326-343.

Aktürk, A.İ. (Çev.). (2005). Osmanlı Mutfağı. İstanbul: Dönence.

Argunşah, M. ve Çakır, M. (Çev.). (2018). 15.Yüzyıl Osmanlı Mutfağı. (3.Basım), İstanbul: Gökkubbe Yayınları.

Ayyıldız, S. ve Sarper, F. (2019). Antioksidan Baharatların Osmanlı Saray Mutfağındaki Yeri, Karabük Üniversitesi Sosyal Bilimler Enstitüsü Dergisi, 9(1): 363-380.

Bayrak, F. (2014). Soframda Anadolu Ege Yemekleri. (2. Basım), İstanbul: Alfa Yayınları.

Berbercan, M. (2016). Yunan Adalarındaki Eski Türk Varlığının Edebî İzleri II: Sakız, Çankırı Karatekin Üniversitesi Karatekin Edebiyat Fakültesi Dergisi, 4(1): 21-34.

Bursa Esnaf ve Sanatkârlar Odaları Birliği. (2012). Bursa'nın Yöresel Lezzetleri. Bursa: Reklamland Bask1.

Coşar, Y. (2017). Somut Olmayan Kültürel Mirasın Korunmasında Kadın Emeğinin Rolü, Sosyal Politika Çalışmaları Dergisi, 17(38): 115-138.

Çalar, N. (2013). Sakız Ağacı (Pistacia lentiscus L.)'nın Pistacia Anaçları (Pistacia vera L., Pistacia khinjuk Stocks, Pistacia atlantica Desf., Pistacia terebinthus L.) Üzerine İn Vitro Mikroaşılanması, Yayınlanmamış Yüksek Lisans Tezi, Dicle Üniversitesi, Diyarbakır.

Çalışkan, R. (2018). Endüstriyel ve Doğal Sakızlar ile İlgili Tüketici Davranışlarının Belirlenmesi Üzerine Bir Araştırma, Yayınlanmamış Yüksek Lisans Tezi, Tekirdağ Namık Kemal Üniversitesi, Tekirdağ.

Çavuşoğlu, M. ve Çavuşoğlu, O. (2018). Gastronomi Turizmi ve Gökçeada Lezzet Rotası, Güncel Turizm Araştırmaları Dergisi, 2(Ek1): 347-359.

Davulcu, A. C. ve Tugay, O. (2018). Osmanlı Döneminde Hekim Yakup Paşa'nın Fatih Sultan Mehmet İçin Yaptığı İlaçlarda Kullanılan Tıbbi Bitkiler, Tarihin Peşinde, Uluslararası Tarih ve Sosyal Araştırmalar Dergisi, (20): 1-15.

Demirel, H. ve Karakuş, H. (2019). Balıkesir Yeme İçme Kültürü ve Değişimi Üzerine Bir Alan Araştırması, Journal of Tourism and Gastronomy Studies, 7(2): 1383-1404.

Dönmez, O. O. (2019). Eski Mısır Uygarlığında Tıp Uygulamaları, Yayınlanmamış Yüksek Lisans Tezi, Pamukkale Üniversitesi, Denizli.

Emecen, F. (2011). Sakız Adasının Sakızları: Küçük Bir Osmanlı Tarım İşletmesi, Osmanlı Araştırmaları, 37(37): 1-16.

Erdönmez, E. (2018). Damla Sakızının (Pistacia lentiscus L.) Antioksidan Aktivitesinin Belirlenmesi, Yayınlanmamış Yüksek Lisans Tezi, Uludağ Üniversitesi, Bursa. 
Fitlamak, K. (2014). İzmir Çeşme Yöresi'ndeki Yabani ve Aşılanmış Sakız Ağaçlarında (Pistacia lentiscus L.) Sakız Üretim Şekilleri ile Yaprak Uçucu Yağ Iç̧eriği ve Bileşenlerinin Belirlenmesi, Yayınlanmamış Yüksek Lisans Tezi, Süleyman Demirel Üniversitesi, Isparta.

Furkan, M. K. (2016). Adıyaman İlinde Yetişen Bazı Bitkilerin Etnobotanik Özellikleri, Yayınlanmamış Yüksek Lisans Tezi, Adıyaman Üniversitesi, Adıyaman.

Güldemir, O. ve Işık, N. (2012). Tatlara Tat Katan Kabuk: Tarçın ve Osmanlı Mutfağındaki Yeri, 1. Türk Mutfak Kültürü Sempozyumu (Osmanlı Mutfak Kültürü), Bilecik Şeyh Edebali Üniversitesi 14-15 Ekim 2010. Bilecik. ss: 311-334.

Gündüzöz, G. (2016). Osmanlı Tekke Mutfak Kültürü ve Mecmuâ-i Fevâid, Cumhuriyet Illahiyat Dergisi, 20(2): 175-205.

Gürsoy, D. (2016). Kuzeyden Güneye...Doğudan Batıya Yöresel Mutfağımız. (5.Basım), İstanbul: Oğlak Yayıncılık.

Hakgüder Taze, B., Ünlütürk, S., Yurt, B., Baştürk, A., Çavuş M. ve Bulut, M. (2014). Damla Sakızının Üretimi ve Sağlığa Faydaları, 4. Geleneksel Gıdalar Sempozyumu, Çukurova Üniversitesi 17-19 Nisan 2014. Adana. ss: 974-977.

Haydaroğlu, İ. (2003). Osmanlı Saray Mutfağından Notlar, Tarih Araştırmaları Dergisi, 22(34): 110.

Hocaoğlu, D. (2010). Kültürel Miras Olarak Yemek Kültürü: Cittàslow Seferihisar'ın Yavaş Yemekleri, 2nd Conference of the Agrindustrial Design, İzmir Ekonomi Üniversitesi 26-28 Nisan 2010. İzmir. ss: 1-21.

https://www.gazetegebze.com.tr/ekonomi/gebze-coregi-gorucuye-cikiyor-h36243.html [Erişim tarihi: 02.05.2020].

https://www.kulturportali.gov.tr/mrepo/eKitap/eb-MuglaMutfagi/54-55/ [Erişim tarihi: 02.05.2020].

Kazancıŏ̆lu, H. (2017). 16. Yüzyıla Ait Bazı Vakfiyeler Işığında Osmanlı Dönemi İmâretleri, Journal of International Social Research, 10(53): 283-301.

Kılıç, M. U. (2019). Sakız Ağacı, Yetiştiriciliği ve Türkiye'deki Varlı̆̆ı, Lisans Tezi, Ege Üniversitesi Ziraat Fakültesi, Bahçe Bitkileri Bölümü, İzmir.

Kılıç, M. U. ve Uysal, H. (2019). Sakız Ağacı (Pistacia lentiscus L. var. chia) ve İn Vitro Rejenerasyonu, International Young Researchers Student Congress, Burdur Mehmet Akif Ersoy Üniversitesi 28-30 Kasım 2019. Burdur. ss: 545-553.

Kılınç, M. F. (2013). Sakız Ağacı (Pistacia lentiscus L.)'nın İn Vitro Klonal Mikroçoğaltılması, Yayınlanmamış Yüksek Lisans Tezi, Dicle Üniversitesi, Diyarbakır.

Koutsoudaki, C., Krsek, M. and Rodger, A. (2005). Chemical Composition and Antibacterial Activity of the Essential Oil and the Gum of Pistacia lentiscus var. chia, Journal Agric Food Chem, 53: 7681-7685.

Mahmoudi, M., Ebrahimzadeh, M. A., Nabavi, S. F., Hafezi, S., Nabavi, S. M. and Eslami, S. H. (2010). Antiinflammatory and Antioxidant Activities of Gum Mastic, European Review for Medical and Pharmacological Sciences, 14(9): 765-769.

Marone, P., Bono, L., Leone, E., Bona, S., Carretto E. and Perversi, L. (2001). Bactericidal Activity of Pistacia lentiscus Mastic Gum Against Helicobacter pylori, Journal of Chemotherapy, 13 (6): 611-614. 
Morkan, L. (2009). Pistacia lentiscus L. (Sakız Ağacı)'da Ağaç Çapı, Boyu ve Üretim Döneminin Sakız Verimine Etkisi, Yayınlanmamış Yüksek Lisans Tezi, Karadeniz Teknik Üniversitesi, Trabzon.

Onay, A., Yıldırım, H. ve Yavuz, M. A. (2016). Sakız Ağacı (Pistacia lentiscus L.) Yetiştiriciliği ve Reçinesi, Batman Üniversitesi Yaşam Bilim Dergisi, 6(2): 133-144.

Orman Genel Müdürlüğü (2014). Sakız Eylem Planı 2014-2019. T.C. Orman ve Su İşleri Bakanlığı.

Özçelik, H. (2018). Tıbbi Sakız Üretimi Amaçlı Türkiye Bitkileri, ISNOS-MED, 22-24 Ekim 2018. Isparta. ss: 239-248.

Özdamla Akkaya, Ö. (2019). Küreselleşme Sürecinde Sosyalleşme Aracı Olarak 3. Dalga Kahveciler ve Tasarım Kültürü, Yayınlanmamış Yüksek Lisans Tezi, Hacettepe Üniversitesi, Ankara.

Özdoğan, A. (2018). Ruşeym ile Zenginleştirilmiş Sakızın Fonksiyonel Özelliklerinin Belirlenmesi, Yayınlanmamış Yüksek Lisans Tezi, Tekirdağ Namık Kemal Üniversitesi, Tekirdağ.

Özlü, Z. (2011). Osmanlılarda Dondurma ve Dondurmacılık Mesleği ile İlgili Notlar, Erdem İnsan ve Toplum Bilimleri Dergisi, (59): 129-144.

Papada, E. and Kaliora, A., C. (2019). Antioxidant and Anti-Inflammatory Properties of Mastiha: A Review of Preclinical and Clinical Studies, Antioxidants, 8(7): 1-12.

Pişkin, N. (2009). (Çev.) Kitâbü't-Tabih: Abbasi Bağdatı'ndan Yemekler, Tatllar, Çeşniler. İstanbul: Kitap Yayınevi.

Rigling, M., Fraatz, M. A., Trögel, S., Sun, J., Zorn, H. and Zhang, Y. (2019). Aroma Investigation of Chios Mastic Gum (Pistacia lentiscus Variety Chia) Using Headspace Gas Chromatography Combined with Olfactory Detection and Chiral Analysis, Journal of Agricultural and Food Chemistry, 67(49): 13420-13429.

Saatcl, G. (2019). Coğrafi İşaretli Yiyeceklerin Tanıtım Unsuru Olarak Yöresel Yemekler Kapsamında Değerlendirilmesi, Journal of Tourism and Gastronomy Studies, 7(1): 358-374.

Sargin, S. A., Selvi, S. and Erdoğan, E. (2013). The Handling Characteristics of the Medicinal Plants Which Sold in Herbalists in Alaşehir (Manisa) Region, Biological Diversity and Conservation, 6(3): 40-45.

Şar, S. ve Süveren, K. (2006). Mücerreb-Nâme'deki Tiryâk Formüllerinin Eczacılık Açısından Değerlendirilmesi, Turkiye Klinikleri Journal of Medical Ethics-Law and History, 14(3): 145-149.

Taşlı, M., Kahraman, K. (2015). Balıkesir Aşı. (1.Baskı), Balıkesir: T.C. Balıkesir Valiliği İl Kültür ve Turizm Müdürlüğ̈̈ Yayınları

Tatll, N. (2017). Geçmişten Günümüze Şerbetler. (1.Basım), İstanbul: İstanbul Büyükşehir Belediyesi Kültür A.Ş. Yayınları.

Toprak, L., Çelikel Güngör, A. ve Gürbüz, S. (2018). Yerel Yemekler: Mardin Örneği, Anadolu I. Uluslararası Multidisipliner Çalışmalar Kongresi, 28-29 Aralık 2018. Diyarbakır. ss: 711-714.

Triantafyllou, A., Bikineyeva, A., Dikalova, A., Nazarewicz, R., Lerakis, S. and Dikalov, S. (2011). Anti-Inflammatory Activity of Chios Mastic Gum is Associated with Inhibition of Tnf-Alpha Induced Oxidative Stres, Nutrition Journal, 10: 1-9.

Tunçdöken, F. (2009). Zeytinbağı (Tirilye)'nin Renkli Yemek Mirası, Uludă̆ Üniversitesi FenEdebiyat Fakültesi Sosyal Bilimler Dergisi, 10(16): 159-166.

Uzel, İ. (1984). 13-18. Yüzyıllar Arasında Anadolu'da Ağız ve Diş Hastalıkları Tedavisi, Gazi Üniversitesi Diş Hekimliği Fakültesi Dergisi. 1(1-2): 178-190. 
Üzümcü, T. P., Alyakut, Ö. ve Akpulat, N. A. (2017). Coğrafi İşaretleme Kapsamında Kocaeli Gastronomik Ürünlerinin Değerlendirilmesi, KMÜ Sosyal ve Ekonomik Araştırmalar Dergisi, 19 (28): 132-140.

Yaşar Keskin, F. (2013). Bir Osmanlı Adasında Toplum ve Ekonomi (XVI. Yüzyıldan XVIII. Yüzyıla Sakız), Yayınlanmamış Doktora Tezi, Hacettepe Üniversitesi, Ankara.

Yerasimos, M. (2014a). Evliya Çelebi Seyahatnâmesi'nde Yemek Kültürü; Yorumlar ve Sistematik Dizin. (2.Basım), İstanbul: Kitap Yayınevi.

Yerasimos, M. (2014b). 500 Yıllık Osmanlı Mutfağı. (13. Basım), İstanbul: Boyut Yayıncılık.

Yılmaz, G. ve Akman, S. (2018). Sürdürülebilir Gastronomi Çerçevesinde Edremit Körfezi Yöresel Mutfakları, Journal of Tourism and Gastronomy Studies, 6(4): 852-872. 